JURNAL MANAJEMEN KOMPETEN

Vol. 4 No. 2 Desember 2021, 101-118

\title{
PENGARUH KUALITAS PELAYANAN TERHADAP KEPUASAN KONSUMEN PADA PT. JNE CABANG SEKAYU
}

\author{
Ika Rakhmalina \\ Ika.rakhmalina1983@gmail.com \\ Yeni Marsih \\ marsihyeni@gmail.com
}

\begin{abstract}
ABSTRAK
Kepuasan pelanggan yang tinggi ditimbulkan oleh kualitas pelayanan yang maksimal.JNE Cabang Sekayu beralamat di Jalan Kolonel Wahid Udin Kelurahan Serasan Jaya Kabupaten Musi Banyuasin. PT JNE Cabang Sekayu menyadari pentingnya kualitas pelayanan yang maksimal kepada pelanggannya agar pelanggan tidak kecewa dan puas dengan terhadap PT. JNE Cabang Sekayu.

Metode yang digunakan dalam penelitian ini adalah metode kuantitatif, jumlah sampel sebanyak 185 responden dengan teknik pengambilan sampel menggunakan teknik slovin. Hasil penelitian ini berupa adanya pengaruh kualitas pelayanan terhadap kepuasan konsumen pada PT. JNE Cabang Sekayu. Berdasarkan analisis data yang dilakukan pengaruh kualitas pelayanan terhadap kepuasan konsumen pada PT. JNE Cabang Sekayu bernilai positif artinya apabila kualitas pelayanan ditingkatkan maka kepuasan konsumen juga akan meningkat, dengan tingkat hubungan yang sedang dan sebesar 21,4\%.

Berdasarkan analisis data tersebut maka untuk meningkatkan kepuasan konsumen maka salah satu cara yang bisa digunakan yaitu dengan meningkatkan kualitas pelayanannya.
\end{abstract}

\section{Kata Kunci: Kualitas Pelayanan, Kepuasan Konsumen.}

\section{PENDAHULUAN}

Pemasaran berperan penting dalam suatu organisasi atau perusahaan, pemasaran adalah aktivitas, serangkaian institusi, dan proses menciptakan, mengomunikasikan, menyampaikan, dan mempertukarkan tawaran yang bernilai bagi pelanggan, klien, mitra, dan masyarakat umum. Perkembangan dunia bisnis yang sangat pesat berdampak pada semakin banyaknya unit usaha baru yang di rintis masyarakat baik yang berskala kecil, menengah maupun berskala besar.Fenomena tersebut diikuti dengan pesatnya perkembangan perusahaan penyedia jasa pengiriman barang atau jasa kurir.

Keberadaan penyedia jasa kurir mampu menunjang para pelaku bisnis karena dapat mengirimkan barang kepada pelanggan baik yang berada di lokasi usaha maupun yang berada jauh diluar dari daerah operasional perusahaan tersebut, sehingga dapat memperluas cakupan pasar yang secara otomatis akan meningkatkan 
keuntungan dari perusahaan. Banyak penjual online shop yang menggunakan jasa kurir tersebut, dengan adanya jasa kurir maka akan memudahkan mereka untuk mengantar barang pesanan sesuai dengan jenis layanan paket yang mereka inginkan. Semakin banyaknya penjual online shop maka jasa kurir pun akan sangat dibutuhkan, tanpa dengan adanya jasa kurir maka barang tidak akan sampai ke tempat tujuan. Maka dari itu perusahaan penyedia jasa pengiriman logistik harus mengutamakan kualitas pelayanannya. (Garside, 2017: 6).Perilaku berbelanja online sudah menjadi kebiasaan banyak orang. Apalagi Indonesia merupakan pasar e-commerce terbesar di Asia Tenggara. Salah satu faktor terbesarnya adalah pertumbuhan kelas menengah di Indonesia yang cukup pesat. Hal ini juga terlihat dengan meningkatnya jumlah pengeluaran masyarakat untuk belanja barang konsumen secara online. faktor yang juga mendukung perkembangan e-commerce adalah tingkat penetrasi internet dan pengguna perangkat mobile yang terus meningkat, memungkinkan lebih banyak orang untuk mengakses berbagai platform belanja online, mulai dari website, toko online, aplikasi marketplace, media sosial, dan banyak lagi.

Faktor lain yang juga ikut berpengaruh adalah semakin banyaknya jumlah perusahaan teknologi finansial sehingga memungkinkan metode pembayaran yang beragam. Dengan munculnya berbagai aplikasi dan fitur pembayaran serta dompet online melalui smartphone, masyarakat semakin dimudahkan untuk melakukan transaksi online. Ditambah lagi, banyak investor asing yang tertarik untuk berinvestasi di perusahaan teknologi e-commerce. Tokopedia misalnya, menerima investasi senilai USD 1,1 miliar dari Alibaba pada tahun 2017 yang akhirnya membuat Tokopedia menjadi perusahaan unicorn. Apabila dilihat dari platform penjualannya, 5 marketplace terbesar di Indonesia berdasarkan jumlah pengunjung bulanannya di kuartal kedua tahun 2020 adalah Shopee (93, 4 juta), Tokopedia (86,1 juta), Bukalapak (35,2 juta), Lazada (22 juta), dan Blibli (18,3 juta). (Setyo, 2020).

Pada saatini banyak perusahaan (termasuk perusahaan jasa) yang menyatakan bahwa tujuan perusahaan yang bersangkutan adalah untuk memuaskan pelanggan. Menurut Lupiyoadi (2014: 192), kepuasan konsumenmerupakan tingkat perasaan dimana seseorang manyatakan hasil perbandingan atas kinerja produk (jasa) yang diterima dan yang diharapkan.Meskipun demikian tidaklah mudah untuk mewujudkan kepuasan pelanggan secara menyeluruh. Kini pelanggan semakin 'terdidik' dan menyadari hak-haknya. Oleh karena itu dapatdipahami bahwa ada kalangan pakar pemasaran yang berpendapat bahwa tidakrealistis bila suatu perusahaan mengharapkan tidak ada pelanggan yang tidak puas. Namun tentu saja setiap perusahaan harus berusaha meminimalkan ketidakpuasan pelanggan dengan memberikan pelayanan yang semakin hari semakin baik dan pada saat bersamaan, perusahaan perlu pula memperhatikan konsumen yang merasa tidak puas. 
Kepuasan pelanggan yang tinggi ditimbulkan oleh kualitas pelayanan yang maksimal dan jika kualitas pelayanan yang diberikan buruk maka harapan konsumen tidak akan pernah tercapai dengan begitu pelanggan akan hilang satu demi satu, hal ini berarti perusahaan tersebut akan bangkrut. Dengan demikian hanya perusahaanperusahaan yang mampu memberikan kepuasan pelanggan yang tinggi yang akan mampu bersaing dan bertahan untuk hidup dan selanjutnya berkembang demi kelangsungan perusahaan.

Menurut Tjiptono (2015: 54) kualitas pelayanan adalah suatu keadaan dinamis yang berkaitan erat dengan produk, jasa, sumber daya manusia, serta proses dan lingkungan yang setidaknya dapat memenuhi atau malah dapat melebihi kualitas pelayanan yang diharapkan.Kualitas pelayanan yang baik adalah upaya yang dapat digunakan oleh perusahaan dalam menghadapi persaingan dalam bidang jasa yang erat kaitannya dengan kepuasan pelanggan. Implementasi kualitas jasa yang dilakukan oleh suatu perusahaan yang bergerak di bidang jasa adalah dengan memberikan kualitas pelayanan (service) yang terbaik bagi konsumen dengan tujuan untuk menciptakan kepuasan konsumen. Kualitas yang di berikan oleh perusahaan, akan menimbulkan persepsi konsumen terhadap kualitas yang diberikan kepadanya. Sering kali terdapat perbedaan antara harapan konsumen dengan persepsi konsumen terhadap kualitas yang diberikan oleh perusahaan. Untuk mengetahui apakah perusahaan telah memberikan kualitas jasa yang sesuai dengan harapan konsumen, maka perlu dilakukan evaluasi dari konsumennya. Kualitas pelayanan yang diharapkan oleh para konsumen adalah fasilitas yang memadai, pelayanan yang baik, kenyamanan, keamanan, ketenangan dan hasil yang memuaskan sehingga pihak manajemen harus memikirkan bagaimana kualitas pelayanan yang baik pada saat ini dapat terus berkembang demi kelancaran dimasa yang akan datang.Kondisi usaha membawa perusahaan khususnya sektor jasa pada suatu kenyataan bahwa kualitas pelayanan menjadi suatu keharusan agar perusahaan tetap sukses, baik tingkat operasional maupun strategi.

JNE yang merupakan perusahaan yang bergerak dalam pengiriman dan logistik yang bermarkas di Jakarta, Indonesia. Nama resminya adalah Tiki Jalur Nugraha Eka Kurir (Tiki JNE). JNE didirikan oleh Soeprapto Suparno pada 26 November 1990. Produk layanan JNE seperti jasa kurir, logistik, money remmittance hingga jasa cargo.

JNE Cabang Sekayu beralamat di Jalan Kolonel Wahid Udin Kelurahan Serasan Jaya Kabupaten Musi Banyuasin. PT JNE Cabang Sekayu menyadari pentingnya kualitas pelayanan yang maksimal kepada pelanggannya agar pelanggan tidak kecewa dan puas dengan terhadap PT. JNE Cabang Sekayu. Dilihat dari keadaan yang ada pelanggan PT. JNE Cabang Sekayu bisa dikatakan kurang puas seperti sering adanya keterlambatan dalam pengiriman barang serta barang yang diterima oleh pelanggan mengalami. Dari keterangan diatasmaka penulis tertarik untuk melakukan penelitian dengan judul:"Pengaruh Kualitas Pelayanan terhadap kepuasan konsumen pada PT. JNE Cabang Sekayu. 


\section{Metodologi Penelitian}

\section{Desain Penelitian}

Sugiyono (2016: 1), mengatakan bahwa "Metode Penelitian pada dasarnya merupakan cara ilmiah untuk mendapatkan data dengan tujuan dan kegunaan tertentu. Cara ilmiah berarti kegiatan penelitian ini didasarkan pada ciri-ciri keilmuan, yaitu rasional, empiris, dan sistematis".

Metode penelitian yang digunakan dalam penelitan ini adalah metode metode kuantitatif. Sugiyono (2016: 14), menjelaskan bahwa metode kuantitatif adalah penelitian dengan metode angka atau data kualitatif yang diangkakan.

\section{Lokasi dan Waktu Penelitian}

Penelitian ini dilaksanakan diJNE Cabang Sekayutepatnya di Jalan Kolonel Wahid Udin Kelurahan Serasan Jaya Kabupaten Musi Banyuasin, dengan jangka waktu penelitian selama 3 (tiga) bulan yaitu dari Maret hingga Mei 2021.

\section{Jenis dan Sumber Data}

Menurut Sujarweni (2014:73) berdasarkan subjek mana asal data penelitian itu diperoleh. Data dapat dibedakan menjadi dua, yaitu sebagai berikut:

1. Data Primer

Data Primer adalah data yang diperoleh dengan survei lapangan yang menggunakan semua metode pengumpulan data orginal. Data primer dari penelitian ini adalah kuesioner yang disebarkan dan dijawab oleh konsumen di JNE Cabang Sekayu.

2. Data Sekunder

Data Sekunder merupakan sumber data yang tidak langsung memberikan data kepada pengumpul data, misalnya lewat orang lain atau lewat dokumen. Data sekunder dari penelitian ini berupa bukti, catatan atau laporan historis yang telah tersusun dalam arsip (data dokumenter) yang ada pada JNE Cabang Sekayu.

\section{Teknik Pengumpulan Data}

Metode pengumpulan data yang penulis lakukan dalam penulisan penelitian ini, menurut Arikunto (2013:256) adalah :

1. Teknik Observasi

Teknik observasi yaitu kegiatan yang dilakukan dengan cara melakukan pengamatan langsung terhadap objek penelitian.

2. Metode angket (Kuesioner)

Metode angket (Kuesioner) adalah sejumlah pertanyaan tertulis yang digunakan untuk memperoleh informasi dari responden dalam arti laporan tentang pribadinya atau hal-hal yang ia ketahui.

3. Metode Dokumentasi

Metode dokumentasi adalah mencari data mengenai hal-hal atau variabel yang berupa catatan, transkrip, buku, surat kabar, majalah, prasasti, notulen rapat, agenda dan sebagainya.

\section{Operasionalisasi Variabel Penelitian}

Operasionalisasi variabel dibuat untuk memudahkan pengumpulan data dan menghindari perbedaan interpensi serta 
membatasi ruang lingkup variabel. Variabel yang dimasukkan dalam operasional adalah variabel penting yang dapat diukur dan dipertanggungjawabkan dengan sumber yang jelas. Definisi operasional penelitian ini dapat dilihat pada tabel berikut ini :

Tabel 1.1

\section{Operasionalisasi Variabel}

\begin{tabular}{|c|c|c|c|c|}
\hline $\begin{array}{l}\text { Variabel } \\
\text { dan } \\
\text { Defenisi } \\
\text { Variabel }\end{array}$ & $\begin{array}{l}\text { Indikat } \\
\text { or }\end{array}$ & \begin{tabular}{|l} 
Skala \\
Pengu \\
kuran
\end{tabular} & \begin{tabular}{|l} 
Jumlah \\
Item \\
Pertan \\
yaan
\end{tabular} & $\begin{array}{l}\text { Nomo } \\
\text { r } \\
\text { Pernya } \\
\text { taan }\end{array}$ \\
\hline $\begin{array}{l}\text { Menurut } \\
\text { Tjiptono } \\
\text { (2015: 54) } \\
\text { kualitas } \\
\text { pelayanan } \\
\text { adalah } \\
\text { suatu } \\
\text { keadaan } \\
\text { dinamis } \\
\text { yang } \\
\text { berkaitan } \\
\text { erat } \\
\text { dengan } \\
\text { produk, } \\
\text { jasa, } \\
\text { sumber } \\
\text { daya } \\
\text { manusia, } \\
\text { serta } \\
\text { proses dan } \\
\text { lingkunga } \\
\text { n yang } \\
\text { setidaknya } \\
\text { dapat } \\
\text { memenuhi } \\
\text { atau } \\
\text { malah } \\
\text { dapat } \\
\text { melebihi } \\
\text { kualitas } \\
\text { pelayanan }\end{array}$ & 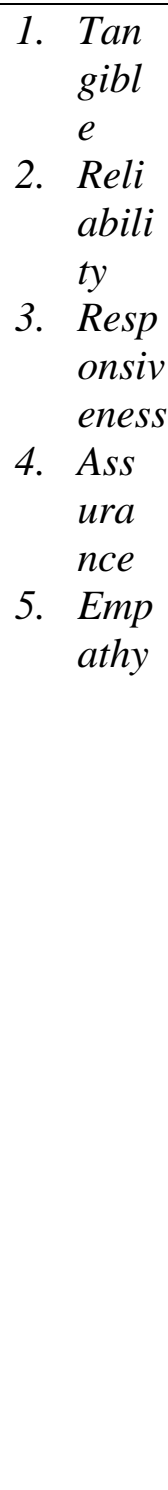 & $\begin{array}{l}\text { Like } \\
\text { rt }\end{array}$ & $\begin{array}{l}2 \\
2 \\
2 \\
2 \\
2\end{array}$ & $\begin{array}{l}1-2 \\
3-4 \\
5-6 \\
7-8 \\
9-10\end{array}$ \\
\hline
\end{tabular}

\begin{tabular}{|c|c|c|c|c|}
\hline $\begin{array}{l}\text { yang } \\
\text { diharapka } \\
\text { n. }\end{array}$ & & & & \\
\hline $\begin{array}{l}\text { Menurut } \\
\text { Lupiyoadi } \\
\text { (2014: } \\
\text { 192) } \\
\text { Kepuasan } \\
\text { Konsume } \\
\text { n } \\
\text { merupaka } \\
\text { n tingkat } \\
\text { perasaan } \\
\text { dimana } \\
\text { seseorang } \\
\text { manyatak } \\
\text { an hasil }\end{array}$ & $\begin{array}{ll}\text { 1. } & \text { Kua } \\
\text { litas } \\
\text { Pela } \\
\text { yan/ } \\
\text { Jasa } \\
\text { 2. } \begin{array}{l}\text { Em } \\
\text { osi }\end{array} \\
\text { 3. Har } \\
\text { ga } \\
\text { 4. } \begin{array}{l}\text { Bia } \\
\text { ya }\end{array}\end{array}$ & $\begin{array}{l}\text { Like } \\
\text { rt }\end{array}$ & $\begin{array}{l}2 \\
2 \\
2\end{array}$ & $\begin{array}{l}1-2 \\
3-4 \\
5-6 \\
7-8\end{array}$ \\
\hline $\begin{array}{l}\text { Variabel } \\
\text { dan } \\
\text { Defenisi } \\
\text { Variabel }\end{array}$ & $\begin{array}{l}\text { Indikat } \\
\text { or }\end{array}$ & $\begin{array}{l}\text { Skala } \\
\text { Pengu } \\
\text { kuran }\end{array}$ & \begin{tabular}{|l|} 
Jumlah \\
Item \\
Pertan \\
yaan
\end{tabular} & \begin{tabular}{|l|} 
Nomo \\
$\mathbf{r}$ \\
Pernya \\
taan
\end{tabular} \\
\hline $\begin{array}{l}\text { perbandin } \\
\text { gan atas } \\
\text { kinerja } \\
\text { produk } \\
\text { (jasa) } \\
\text { yang } \\
\text { diterima } \\
\text { dan yang } \\
\text { diharapka } \\
\text { n. }\end{array}$ & & & & \\
\hline
\end{tabular}

\section{Variabel Penelitian}

Sugiyono (2016: 38) menjelaskan bahwa variabel adalah segala sesuatu yang berbentuk apa saja yang ditetapkan oleh peneliti untuk dipelajari sehingga diperoleh informasi tentang hal tersebut. Adapun variabel-variabel yang diteliti adalah sebagi berikut : 
a. Variabel Bebas (Independent Variable) Variabel bebas adalah suatu variabel yang dapat mempengaruhi variabel lainnya. Dalam penelitian ini yang menjadi variabel bebas adalah kualitas pelayananyang dilambangkan dengan $\mathrm{X}$.

b. Variabel Terikat (Dependent Variable) Variabel terikat adalah suatu variabel yang dipengaruhi oleh variabel bebas. Yang menjadi variabel terikat dalam penelitian ini adalahkepuasan konsumenyang dilambangkan Y.

\section{Skala Pengukuran Penelitian}

Menurut Ramli (2011:43) skala pengukuran adalah kesepakatan yang digunakan sebagai acuan atau tolak ukur untuk menentukan panjang pendeknya interval yang ada pada alat ukur sehinga alat ukur tersebut bila digunakan dalam pengukuran akan menghasilkan data. Skala pengukuran dalam penelitian ini adalah Skala Likert. Menurut Sugiyono (2016: 132) Skala Likert digunakan untuk mengukur sikap, pendapat, dan persepsi seseorang atau sekelompok orang tentang fenomena sosial."

\section{Instrumen Penelitian}

Instrumen penelitian adalah semua alat yang digunakan untuk mengumpulkan, memeriksa, menyelidiki masalah, atau mengolah, menganalisa dan menyajikan data-data secara sistematis serta objektif dengan tujuan memecahkan suatu persoalan atau menguji suatu hipotesis. Instrumen yang digunakan dalam penelitian ini berupa kuesioner. Kuesioner tersebut berisi seperangkat daftar pertanyaan ataupun pernyataan tertulis kepada responden yang menjadi anggota sampel penelitian untuk dijawab. Angket yang digunakan mengenai manajemen kualitas pelayanan dan kepuasan konsumen. Skala penilaian jawaban yang digunakan adalah skala likert lima kategori yaitu sebagai berikut :

$\begin{array}{ll}\text { STS (sangat tidak setuju) } & =1 \\ \text { TS (tidak setuju) } & =2 \\ \text { RR (ragu-ragu) } & =3 \\ \text { S (setuju) } & =4 \\ \text { SS (sangat setuju) } & =5\end{array}$

\section{Populasi}

Menurut Sugiyono (2016:115), "Populasi adalah wilayah generalisasi terdiri atas objek/subjek yang mempunyai kualitas dan karakteristik tertentu. ditetapkan oleh peneliti untuk dipelajari dan kemudian ditarik kesimpulannya". Populasi dalam penelitian ini adalah seluruh konsumen PT. JNE khususnya bulan Maret 2021 yang berjumlah 345 konsumen.

\section{Sampel}

Sugiyono (2016:117) berpendapat bahwa sampel adalah sebagian dari jumlah dan karakteristik yang dimiliki oleh populasi tersebut. Sugiyono (2016:149) mengatakan bahwa apabila dalam sebuah penelitian populasinya lebih dari 100 orang maka penentuan sampel menggunakan teknik slovin, perhitungan menggunakan teknik slovin dengan kesalahannya 5\%, sebagai berikut: $\mathrm{n}=\frac{N}{1+N e^{2}}$ 


$$
\begin{aligned}
& =\frac{345}{1+345(0,05)^{2}}=\frac{345}{1+345(0,0025)} \\
& =\frac{345}{1,86}=185,48(185 \text { responden })
\end{aligned}
$$

\section{Teknik Pengambilan Sampel}

Dalam menentukan sampel, teknik sampling yang digunakan dalam penelitian ini adalah Sampling Aksidental. Menurut Sugiyono (2016: 60) Aksidental Sampling adalah teknik penentuan sampel berdasarkan kebetulan, yaitu siapa saja yang secara kebetulan bertemu dengan peneliti dapat digunakan sebagai sampel, bila dipandang orang yang kebetulan ditemui itu cocok sebagai sumber data.

\section{Teknik Analisis Data}

Analisis data yang digunakan dalam penelitian ini menggunakan bantuan SPSS versi 25. Kegiatan dalam analisis data adalah mengelompokkan data berdasarkan variabel dan jenis responden, menyajikan data tiap variabel yang diteliti, melakukan perhitungan untuk menjawab rumusan masalah, dan melakukan perhitungan untuk menguji hipotesis yang telah diajukan.

\section{Uji Validitas}

Arikunto (2013: 130) menjelaskan validitas adalah keadaan yang menggambarkan tingkat instrumen bersangkutan yang mampu mengukur apa yang akan diukur.

Uji validitas item atau butir kuesioner dapat dilakukan dengan menggunakan program SPSS versi 25. Untuk proses ini, akan digunakan Uji Correlation Product Moment. Dalam uji ini, setiap item akan diuji relasinya dengan skor total variabel yang dimaksud. Dalam hal ini masing-masing item yang ada di dalam variabel $\mathrm{X}$ dan $\mathrm{Y}$ akan diuji relasinya dengan skor total variabel tersebut.

\section{Dengan kriteria :}

a. jika $r$ hitung $>r$ tabel dengan tingkat signifikansi sebesar 5\% maka item kuesioner penelitian dapat dikatakan valid atau layak dijadikan item pertanyaan dalam penelitan.

b. jika $r$ hitung $<\mathrm{r}$ tabel dengan tingkat signifikansi sebesar 5\% maka item kuesioner penelitian dapat dikatakan tidak valid atau tidak layak dijadikan item pertanyaan dalam penelitan.

\section{Uji Reliabilitas}

Menurut Sujarweni (2015: 110) uji reliabilitas merupakan ukuran suatu kestabilan dan konsistensi responden dalam menjawab hal yang berkaitan dengan konstruk - konstruk pertanyaan yang merupakan dimensi suatu variabel dan disusun dalam suatu bentuk kuesioner. Uji reliabilitas dapat dilakukan secara bersama sama terhadap seluruh butir pertanyaan. Hasil uji reliabilitas menunjukkan bahwa alat ukur yang digunakan reliabel apabila nilai Alpha Cronbach> 0.60 maka instrumen dinyatakan reliabel.

Untuk menguji reliabilitas instrumen dalam penelitian ini yaitu menggunakan uji cronbach alpha. Reliabilitas item diuji dengan melihat koefisien alpha dengan reliability analysis dengan program SPSS versi 20.

\section{Analisis Regresi Sederhana}


Analisis regresi yang digunakan dalam penelitian ini adalah analisis regresi linear sederhana. Analisis regresi linear sederhana adalah suatu analisis yang hanya berkaitan dengan dua variabel saja, yang disebut variabel independen (variabel bebas) yang biasanya diberi notasi $\mathrm{X}$ dan variabel dependen (variabel terikat) yang biasanya diberi notasi Y. Analisis ini digunakan oleh peneliti untuk mengetahui adakah pengaruh pada variabel bebas dapat mempengaruhi variabel terikat. Yang digambarkan dalam persamaan berikut:

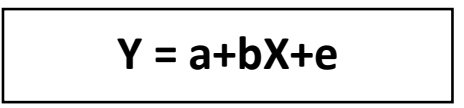

Dimana:

$$
\begin{aligned}
\mathrm{Y} & =\text { Kepuasan Konsumen } \\
\mathrm{X} & =\text { Kualitas Pelayanan } \\
\mathrm{a} & =\text { Konstanta } \\
\mathrm{b} & =\text { Koefisien regresi }
\end{aligned}
$$

\section{Analisis Korelasi}

Analisis korelasi sederhana (Bivariate Correlation) digunakan untuk mengetahui keeratan hubungan antara dua variabel dan untuk mengetahui arah hubungan yang terjadi. Tingkat hubungan tersebut dapat dibagi menjadi tiga kriteria, yaitu mempunyai hubungan positif, mempunyai hubungan negatif, dan tidak mempunyai hubungan.

$$
\text { Menurut Sugiyono (2016: 265), }
$$
pedoman untuk memberikan interprestasikoefisien korelasi sebagai berikut :
a. $0,00-0,199=$ sangat rendah
b. $0,20-0,399$
c. $0,40-0,599$
$=$ rendah

$$
\begin{array}{ll}
\text { d. } 0,60-0,799 & =\text { sedang } \\
\text { e. } 0,80-1,000 & =\text { kuat } \\
& =\text { sangat kuat }
\end{array}
$$

\section{Analisis Determinasi}

Menurut Ghazali (2016: 65), Ujikoefisien determinasi $\left(\mathrm{R}^{2}\right)$ digunakan untuk mengukur seberapa jauh kemampuan model dalam menerangkan variasi variabel dependen. Apabila nilai koefisien korelasi sudah diketahui, maka untuk mendapatkan koefisien determinasi dapat diperoleh dengan mengkuadratkannya.

\section{Uji Hipotesis}

Menurut Sugiyono (2016: 273) mengatakan hipotesis harus dapat diuji untuk mendapatkan atau menolaknya, hal tersebut dapat dilakukan dengan mengumpulkan data empiris. Uji Hipotesis yang digunakan dalam penelitian ini adalah uji $\mathrm{t}$ yang digunakan untuk mengetahui apakah hubungan yang terjadi itu berlaku untuk populasi (dapat digeneralisasi).

Langkah-langkah pengujian sebagai berikut :

1. Menentukan Hipotesis

2. Menentukan tingkat signifikansi

Pengujian menggunakan uji dua sisi dengan tingkat signifikansi $\alpha=5 \%$. Tingkat signfikansi berarti mengambil resiko salah dalam mengambil keputusan untuk menolak hipotesis yang benar sebanyak-banyaknya $5 \%$.

3. Kriteria pengujian
a. Jika $\mathrm{t}$ Hitung $<\mathrm{t}$ tabel maka Ho diterima dan Ha ditolak 
JURNAL MANAJEMEN KOMPETEN

Vol. 4 No. 2 Desember 2021, 101-118

b. Jika $\mathrm{t}$ Hitung $>\mathrm{t}$ tabel Maka Ho ditolak dan Ha diterima.

Untuk menentukan t tabel digunakan rumus $\mathrm{Df}=\mathrm{n}$-k.Dimana $\mathrm{n}$ - banyaknya variabel dan $\mathrm{k}=$ banyaknya variabel.

\section{Pembahasan}

\section{Deskripsi Responden}

Pada bagian ini diuraikan dan dijelaskan mengenai deskripsi responden. Deskripsi responden dalam penelitian ini berupa jenis kelamin, usia, status perkawinan, tingkat pendidikan. Berikut ini adalah data yang penulis peroleh mengenai profil responden, yaitu :

\section{Tabel 4.1}

Deskripsi Responden Berdasarkan Jenis Kelamin

\begin{tabular}{|c|l|c|c|}
\hline No & $\begin{array}{c}\text { Jenis } \\
\text { Kelamin }\end{array}$ & $\begin{array}{c}\text { Jumlah } \\
\text { Responden } \\
\text { (Orang) }\end{array}$ & Persentase \\
\hline 1. & Laki -Laki & 60 & 32,43 \\
\hline 2. & Perempuan & 125 & 67,57 \\
\hline \multicolumn{2}{|c|}{ Total } & $\mathbf{1 8 5}$ & $\mathbf{1 0 0}$ \\
\hline
\end{tabular}

Sumber : data primer (diolah),2021

Dari tabel 4.1 dapat kita lihat, bahwa responden responden yang berjenis kelamin laki-laki sebanyak 60 responden $(32,43 \%)$ dan responden yan berjenis kelamin perempuan sebanyak 125 responden $(67,57 \%)$.

Tabel 4.2

Deskripsi Responden Berdasarkan Usia

\begin{tabular}{|c|l|c|c|}
\hline No & Usia & $\begin{array}{c}\text { Jumlah } \\
\text { Responden } \\
\text { (Orang) }\end{array}$ & Persentase \\
\hline 1. & $\begin{array}{l}<21 \\
\text { Tahun }\end{array}$ & 49 & 26,49 \\
\hline 2. & $\begin{array}{l}21-40 \\
\text { tahun }\end{array}$ & 93 & 50,27 \\
\hline 3 & $\begin{array}{l}>40 \\
\text { tahun }\end{array}$ & 43 & 23,24 \\
\hline \multicolumn{2}{|c|}{ Total } & $\mathbf{1 8 5}$ & $\mathbf{1 0 0}$ \\
\hline
\end{tabular}

Sumber : data primer (diolah),2021

Dari tabel 4.1 dapat kita lihat, bahwa responden responden yang berusia dibawah 21 tahun sebanyak 49 responden $(26,49 \%)$, responden yang berusia21-40 tahun sebanyak 93 responden $(50,27 \%)$, responden yang berusia diatas 40 tahunsebanyak 43 responden $(23,24 \%)$.

Tabel 4.3

Deskripsi Responden Berdasarkan Status Perkawinan

\begin{tabular}{|c|l|c|c|}
\hline No & $\begin{array}{c}\text { Status } \\
\text { Pernikahan }\end{array}$ & $\begin{array}{c}\text { Jumlah } \\
\text { Responden } \\
\text { (Orang) }\end{array}$ & Persentase \\
\hline 1. & Menikah & 79 & 42,70 \\
\hline 2. & $\begin{array}{l}\text { Belum } \\
\text { Menikah }\end{array}$ & 106 & 57,30 \\
\hline \multicolumn{2}{|c|}{ Total } & $\mathbf{1 8 5}$ & $\mathbf{1 0 0 \%}$ \\
\hline
\end{tabular}

Sumber : data primer (diolah),2021

Dari tabel 4.3 dapat kita lihat bahwa, responden yang sudah menikah sebanyak 79 responden $(42,70 \%)$ dan responden yang 
JURNAL MANAJEMEN KOMPETEN

Vol. 4 No. 2 Desember 2021, 101-118

belum menikah sebanyak 106 responden $(57,30 \%)$.

Tabel 4.4

Deskripsi Responden Berdasarkan

Pendidikan

\begin{tabular}{|c|c|c|c|}
\hline No & Usia & $\begin{array}{c}\text { Jumlah } \\
\text { Responden } \\
\text { (Orang) }\end{array}$ & Persentase \\
\hline 1. & $\begin{array}{l}\text { Dibawah } \\
\text { SMA }\end{array}$ & 35 & 18,92 \\
\hline 2. & SMA & 99 & 53,51 \\
\hline 3. & $\begin{array}{l}\text { Diploma } \\
\text { Tiga }\end{array}$ & 14 & 7,57 \\
\hline 4. & Sarjana & 33 & 17,84 \\
\hline 5 & Magister & 4 & 2,16 \\
\hline & Total & 185 & $100 \%$ \\
\hline
\end{tabular}

Sumber : data primer (diolah), 2021

Dari tabel 4.4 dapat kita lihat bahwa, responden yang berpendidikan dibawah SMA sebanyak 35 responden (18,92\%), SMA sebanyak99 responden $(53,51 \%)$, responden yang berpendidikan diploma tiga sebanyak 14 responden $(7,57 \%)$, responden yang berpendidikan sarjana sebanyak 33 responden $(17,84 \%)$ dan responden yang berpendidikan Magister sebanyak 4 responden $(2,16 \%)$.

\section{Distribusi Jawaban Responden}

\section{Distribusi Jawaban Responden Mengenai} kualitas pelayanan

Berdasarkan tanggapan responden dari 10 (sepuluh) pernyataan yang diajukan mengenai kualitas pelayanan (X) didapat distribusi dan rekapitulasi sebagai berikut :

\section{Tabel 4.5}

Distribusi Jawaban Responden Mengenai Kualitas Pelayanan

\begin{tabular}{|c|c|c|c|}
\hline \multirow{2}{*}{$\begin{array}{l}\mathbf{N} \\
\mathbf{0}\end{array}$} & \multirow{2}{*}{$\begin{array}{c}\text { Kuesioner/Jawab } \\
\text { an }\end{array}$} & \multicolumn{2}{|c|}{ Jumlah } \\
\hline & & $\begin{array}{c}\text { Frekuen } \\
\text { si }\end{array}$ & $(\%)$ \\
\hline 1 & $\begin{array}{l}\text { Tata cara } \\
\text { pengiriman dan } \\
\text { pengambilan } \\
\text { barang di JNE } \\
\text { Cabang Sekayu } \\
\text { mudah } \\
\text { a. Sangat setuju } \\
\text { b. Setuju } \\
\text { c. Ragu-ragu } \\
\text { d. Tidak setuju } \\
\text { e. Sangat tidak } \\
\text { setuju }\end{array}$ & $\begin{array}{c}54 \\
59 \\
47 \\
20 \\
5\end{array}$ & $\begin{array}{c}29,1 \\
9 \\
31,8 \\
9 \\
25,4 \\
1 \\
10,8 \\
1 \\
2,70\end{array}$ \\
\hline
\end{tabular}

\begin{tabular}{|c|c|c|c|}
\hline \multirow{2}{*}{$\begin{array}{l}\mathbf{N} \\
\mathbf{0}\end{array}$} & \multirow{2}{*}{$\begin{array}{c}\text { Kuesioner/Jawab } \\
\text { an }\end{array}$} & \multicolumn{2}{|c|}{ Jumlah } \\
\hline & & $\begin{array}{c}\text { Frekuen } \\
\text { si }\end{array}$ & $(\%)$ \\
\hline 2 & $\begin{array}{l}\text { Pengiriman barang } \\
\text { oleh JNE Cabang } \\
\text { Sekayu selalu tepat } \\
\text { waktu } \\
\text { a. Sangat setuju } \\
\text { b. Setuju } \\
\text { c. Ragu-ragu } \\
\text { d. Tidak setuju } \\
\text { e. Sangat tidak } \\
\text { setuju }\end{array}$ & $\begin{array}{l}51 \\
71 \\
34 \\
19 \\
10\end{array}$ & $\begin{array}{c}27,5 \\
7 \\
38,3 \\
8 \\
18,3 \\
8 \\
10,2 \\
7 \\
5,41\end{array}$ \\
\hline 3 & $\begin{array}{l}\text { Karyawan JNE } \\
\text { Cabang Sekayu }\end{array}$ & & \\
\hline
\end{tabular}


JURNAL MANAJEMEN KOMPETEN

Vol. 4 No. 2 Desember 2021, 101-118

\begin{tabular}{|c|c|c|c|}
\hline & $\begin{array}{l}\text { cermat dalam } \\
\text { melakukan } \\
\text { pekerjaannya } \\
\text { a. Sangat setuju } \\
\text { b. Setuju } \\
\text { c. Ragu-ragu } \\
\text { d. Tidak setuju } \\
\text { e. Sangat tidak } \\
\text { setuju }\end{array}$ & $\begin{array}{l}48 \\
65\end{array}$ & $\begin{array}{c}25,9 \\
5 \\
35,1 \\
4 \\
24,3 \\
2 \\
8,11 \\
6,49\end{array}$ \\
\hline 4 & $\begin{array}{l}\text { JNE Cabang } \\
\text { Sekayu } \\
\text { mempunyai } \\
\text { standar dalam } \\
\text { melayani } \\
\text { konsumennya } \\
\text { a. Sangat setuju } \\
\text { b. Setuju } \\
\text { c. Ragu-ragu } \\
\text { d. Tidak setuju } \\
\text { e. Sangat tidak } \\
\text { setuju }\end{array}$ & $\begin{array}{l}62 \\
64 \\
37 \\
17\end{array}$ & $\begin{array}{c}33,5 \\
1 \\
34,5 \\
9 \\
20,0 \\
0 \\
9,19 \\
5,95\end{array}$ \\
\hline 5 & $\begin{array}{l}\text { Karyawan JNE } \\
\text { Sekayu selalu } \\
\text { merespon setiap } \\
\text { pelanggan/pemoho } \\
\text { n yang ingin } \\
\text { mendapatkan } \\
\text { pelayanan atau } \\
\text { mengirim barang } \\
\text { a. Sangat setuju } \\
\text { b. Setuju } \\
\text { c. Ragu-ragu } \\
\text { d. Tidak setuju } \\
\text { e. Sangat tidak } \\
\text { setuju }\end{array}$ & $\begin{array}{l}64 \\
29\end{array}$ & $\begin{array}{c}30,8 \\
1 \\
34,5 \\
9 \\
15,6 \\
8 \\
7,57 \\
8,65\end{array}$ \\
\hline
\end{tabular}

\begin{tabular}{|c|c|c|c|}
\hline 6 & $\begin{array}{l}\text { Karyawan JNE } \\
\text { Sekayu selalu } \\
\text { merespon setiap } \\
\text { keluhan } \\
\text { konsumennya. } \\
\text { a. Sangat setuju } \\
\text { b. Setuju } \\
\text { c. Ragu-ragu } \\
\text { d. Tidak setuju } \\
\text { e. Sangat tidak } \\
\text { setuju }\end{array}$ & $\begin{array}{l}57 \\
63 \\
37 \\
21\end{array}$ & $\begin{array}{c}30,8 \\
1 \\
34,0 \\
5 \\
20,0 \\
0 \\
11,3 \\
5 \\
3,78\end{array}$ \\
\hline 7 & $\begin{array}{l}\text { Karyawan selalu } \\
\text { memberikan } \\
\text { informasi tentang } \\
\text { barang konsumen } \\
\text { dan memberikan } \\
\text { informasi terbaru } \\
\text { mengenai } \\
\text { peraturan dan } \\
\text { program terbaru } \\
\text { dari JNE } \\
\text { a. Sangat setuju } \\
\text { b. Setuju } \\
\text { c. Ragu-ragu } \\
\text { d. Tidak setuju } \\
\text { e. Sangat tidak } \\
\quad \text { setuju }\end{array}$ & $\begin{array}{l}54 \\
64 \\
29 \\
19 \\
12\end{array}$ & $\begin{array}{c}29,1 \\
9 \\
34,5 \\
9 \\
15,6 \\
8 \\
10,2 \\
7 \\
6,49\end{array}$ \\
\hline 8 & $\begin{array}{l}\text { JNE Sekayu } \\
\text { menjamin barang } \\
\text { yang akan datang } \\
\text { tanpa cacat } \\
\text { ataupun tertukar } \\
\text { dengan }\end{array}$ & & \\
\hline $\mathbf{N}$ & Kuesioner/Jawab & & \\
\hline
\end{tabular}


JURNAL MANAJEMEN KOMPETEN

Vol. 4 No. 2 Desember 2021, 101-118

\begin{tabular}{|c|c|c|c|}
\hline о & an & Frekuen & $(\%)$ \\
\hline & $\begin{array}{l}\text { a. Sangat setuju } \\
\text { b. Setuju } \\
\text { c. Ragu-ragu } \\
\text { d. Tidak setuju } \\
\text { e. Sangat tidak } \\
\text { setuju }\end{array}$ & $\begin{array}{c}50 \\
62 \\
41 \\
19 \\
9\end{array}$ & $\begin{array}{c}27,0 \\
3 \\
33,5 \\
1 \\
22,1 \\
6 \\
10,2 \\
7 \\
4,86\end{array}$ \\
\hline 9 & $\begin{array}{l}\text { Karyawan JNE } \\
\text { Cabang Sekayu } \\
\text { selalu } \\
\text { mendahulukan } \\
\text { kepentingan } \\
\text { konsumennya } \\
\text { a. Sangat setuju } \\
\text { b. Setuju } \\
\text { c. Ragu-ragu } \\
\text { d. Tidak setuju } \\
\text { e. Sangat tidak } \\
\text { setuju }\end{array}$ & $\begin{array}{c}59 \\
63 \\
54 \\
16 \\
5\end{array}$ & $\begin{array}{c}31,8 \\
9 \\
34,0 \\
5 \\
29,1 \\
9 \\
8,65 \\
2,70\end{array}$ \\
\hline 10 & $\begin{array}{l}\text { Karyawan JNE } \\
\text { Sekayu melayani } \\
\text { dengan tidak } \\
\text { diskriminatif } \\
\text { (membeda- } \\
\text { bedakan) setiap } \\
\text { konsumen } \\
\text { a. Sangat setuju } \\
\text { b. Setuju } \\
\text { c. Ragu-ragu } \\
\text { d. Tidak setuju } \\
\text { e. Sangat tidak } \\
\text { setuju }\end{array}$ & $\begin{array}{l}37 \\
61 \\
38 \\
13\end{array}$ & $\begin{array}{c}20,0 \\
0 \\
32,9 \\
7 \\
20,5 \\
4 \\
7,03\end{array}$ \\
\hline
\end{tabular}

\begin{tabular}{|l|l|l|l|}
\hline & & & 7,57 \\
\hline
\end{tabular}

Sumber : data primer (diolah), 2021

\section{Distribusi Jawaban Responden Mengenai Kepuasan Konsumen}

Berdasarkan tanggapan responden dari 8 (delapan) pernyataan yang diajukan mengenai kepuasan konsumen (Y) didapat distribusi dan rekapitulasi sebagai berikut :

Tabel 4.6

Distribusi Jawaban Responden Mengenai Kepuasan Konsumen

\begin{tabular}{|c|c|c|c|}
\hline \multirow{2}{*}{$\begin{array}{l}\mathbf{N} \\
\mathbf{0}\end{array}$} & \multirow{2}{*}{$\begin{array}{c}\text { Kuesioner/Jawab } \\
\text { an }\end{array}$} & \multicolumn{2}{|c|}{ Jumlah } \\
\hline & & $\begin{array}{c}\text { Frekuen } \\
\text { si }\end{array}$ & $(\%)$ \\
\hline 1 & $\begin{array}{l}\text { Karyawan JNE } \\
\text { Sekayu } \\
\text { memberikan } \\
\text { pelayan yang baik } \\
\text { kepada konsumen } \\
\text { a. Sangat setuju } \\
\text { b. Setuju } \\
\text { c. Ragu-ragu } \\
\text { d. Tidak setuju } \\
\text { e. Sangat tidak } \\
\text { setuju }\end{array}$ & $\begin{array}{l}58 \\
57 \\
42 \\
19\end{array}$ & $\begin{array}{c}31,3 \\
5 \\
30,8 \\
1 \\
22,7 \\
0 \\
10,2 \\
7 \\
4,86\end{array}$ \\
\hline 2 & $\begin{array}{l}\text { Konsumen merasa } \\
\text { puas karena } \\
\text { mendapatkan } \\
\text { pelayanan sesuai } \\
\text { dengan } \\
\text { keinginannya } \\
\text { a. Sangat setuju } \\
\text { b. Setuju } \\
\text { c. Ragu-ragu } \\
\text { d. Tidak setuju }\end{array}$ & $\begin{array}{l}41 \\
71 \\
43 \\
18\end{array}$ & $\begin{array}{c}22,6 \\
1 \\
38,3 \\
8 \\
23,2\end{array}$ \\
\hline
\end{tabular}


JURNAL MANAJEMEN KOMPETEN

Vol. 4 No. 2 Desember 2021, 101-118

\begin{tabular}{|c|c|c|c|}
\hline & $\begin{array}{ll}\text { e. } & \begin{array}{l}\text { Sangat tidak } \\
\text { setuju }\end{array}\end{array}$ & 6 & $\begin{array}{c}4 \\
9,73 \\
3,24\end{array}$ \\
\hline 3 & $\begin{array}{l}\text { Konsumen merasa } \\
\text { puas ketika } \\
\text { menggunakan jasa } \\
\text { JNE Cabang } \\
\text { Sekayu karena } \\
\text { JNE Cabang } \\
\text { Sekayu merupakan } \\
\text { jasa pengiriman } \\
\text { logistik terbaik } \\
\text { a. Sangat setuju } \\
\text { b. Setuju } \\
\text { c. Ragu-ragu } \\
\text { d. Tidak setuju } \\
\text { e. Sangat tidak } \\
\text { setuju }\end{array}$ & $\begin{array}{l}60 \\
46\end{array}$ & $\begin{array}{c}25,4 \\
1 \\
32,4 \\
3 \\
24,8 \\
6 \\
11,3 \\
5 \\
5,95\end{array}$ \\
\hline 4 & $\begin{array}{l}\text { Konsumen merasa } \\
\text { puas karena } \\
\text { mayoritas } \\
\text { masyarakat } \\
\text { menggunakan jasa } \\
\text { JNE Cabang } \\
\text { Sekayu. } \\
\text { a. Sangat setuju } \\
\text { b. Setuju } \\
\text { c. Ragu-ragu } \\
\text { d. Tidak setuju } \\
\text { e. Sangat tidak } \\
\text { setuju }\end{array}$ & $\begin{array}{l}54 \\
66 \\
46\end{array}$ & $\begin{array}{c}29,1 \\
9 \\
35,6 \\
8 \\
24,8 \\
6 \\
11,3 \\
5 \\
5,95\end{array}$ \\
\hline 5 & $\begin{array}{l}\text { Konsumen merasa } \\
\text { puas dengan harga } \\
\text { yang ditawarkan }\end{array}$ & & \\
\hline
\end{tabular}

\begin{tabular}{|c|c|c|c|}
\hline & $\begin{array}{l}\text { oleh JNE Cabang } \\
\text { Sekayu murah } \\
\text { a. Sangat setuju } \\
\text { b. Setuju } \\
\text { c. Ragu-ragu } \\
\text { d. Tidak setuju } \\
\text { e. Sangat tidak } \\
\text { setuju }\end{array}$ & $\begin{array}{l}51 \\
66 \\
45\end{array}$ & $\begin{array}{c}27,5 \\
7 \\
35,6 \\
8 \\
24,3 \\
2 \\
9,73 \\
2,70\end{array}$ \\
\hline 6 & $\begin{array}{l}\text { Konsumen merasa } \\
\text { puas karena harga } \\
\text { yang ditawarkan } \\
\text { JNE Sekayu sesuai } \\
\text { dengan yang } \\
\text { didapat oleh } \\
\text { konsumen } \\
\text { a. Sangat setuju } \\
\text { b. Setuju } \\
\text { c. Ragu-ragu } \\
\text { d. Tidak setuju } \\
\text { e. Sangat tidak } \\
\text { setuju }\end{array}$ & $\begin{array}{l}53 \\
69 \\
28\end{array}$ & $\begin{array}{c}28,6 \\
5 \\
37,3 \\
0 \\
15,1 \\
4 \\
14,0 \\
5 \\
4,86\end{array}$ \\
\hline 7 & $\begin{array}{l}\text { Konsumen merasa } \\
\text { puas karena barang } \\
\text { diatarkan ke } \\
\text { alamat rumah } \\
\text { sehingga tidak } \\
\text { membuang waktu } \\
\text { untuk mengambil } \\
\text { sendiri } \\
\text { a. Sangat setuju } \\
\text { b. Setuju } \\
\text { c. Ragu-ragu } \\
\text { d. Tidak setuju } \\
\text { e. Sangat tidak } \\
\text { setuju }\end{array}$ & $\begin{array}{l}63 \\
44\end{array}$ & $\begin{array}{c}28,1 \\
1 \\
34,0 \\
5 \\
23,7 \\
8 \\
10,2 \\
7\end{array}$ \\
\hline
\end{tabular}




\begin{tabular}{|c|l|c|c|}
\hline 8 & $\begin{array}{l}\text { Konsumen merasa } \\
\text { puas karena barang } \\
\text { diatarkan ke } \\
\text { alamat rumah } \\
\text { sehingga } \\
\text { konsumen tidak } \\
\text { membuang biaya } \\
\text { tambahan ketika } \\
\text { pergi ke kantor }\end{array}$ & 63 & 3,78 \\
$\begin{array}{l}\text { JNE Cabang } \\
\text { Sekayu }\end{array}$ & 55 & 54,0 \\
$\begin{array}{l}\text { a. Sangat setuju } \\
\text { b. Setuju } \\
\text { c. Ragu-ragu } \\
\text { d. Tidak setuju } \\
\text { e. Sangat tidak }\end{array}$ & 18 & 21,6 \\
$\quad$ setuju & 9 & 29,7 \\
\hline
\end{tabular}

Sumber : data primer (diolah),2021

\section{Uji Instrumen Penelitian}

\section{Uji Validitas}

Suatu instrumen pengumpul data dikatakan validjika mampu dan dapat mengungkap data atau informasi dari suatu variabel yang diteliti secara tepat dan mampu mengukur apa yang diinginkan atas penelitian tersebut. Teknik pengujiannya menggunakan teknik korelasi product moment dari pearson dengan taraf signfikansi sebesar 5\%. Caranya dengan mengkorelasi antara skor item pernyataan dengan skor total dengan menggunakan bantuan program SPSS Versi 20. Dengan kriteria pengujian koefisien korelas (r)> rtabel dapat dinyatakan valid. Nilai r-tabel yang didapat untuk 185 responden sebesar 0,205 .

Dari hasil uji validitas variable kualitas pelayanan dapat diketahui bahwa semua item variabel $\mathrm{x}$ dapat dikatakan valid. Dengan cara membandingkan nilai $r$ hitung dengan $r$ tabel. Dengan kriteria pengujian koefisien korelasi> $r$ tabel. Nilai $r$ tabel pada signifikanasi 5\% adalah sebesar 0,144. Maka dapat dikatakan nilai $r$ hitung keseluruhan item variabel kualitas pelayanan (X) lebih besar dari $r$ tabel. Sehingga dapat digunakan untuk mengukur instrumen dalam penelitian.

Dari hasil uji validitas variable kepuasan konsumen dapat diketahui bahwa semua item variabel y dapat dikatakan valid. Dengan cara membandingkan nilai $r$ hitung dengan $r$ tabel. Dengan kriteria pengujian nilai alpha $>\mathrm{r}$ tabel. Nilai $\mathrm{r}$ tabel pada signifikanasi $5 \%$ adalah sebesar 0,144. Maka dapat dikatakan nilai $r$ hitung keseluruhan item variabel $\mathrm{Y}$ (kepuasan konsumen) lebih besar dari $r$ tabel. Sehingga dapat digunakan untuk mengukur instrumen dalam penelitian.

\section{Uji Reliabilitas}

Uji reliabilitas adalah indeks yang menunjukkan sejauh mana alat pengukur dapat dipercaya atau diandalkan. Untuk menguji kehandalan variabel dari item dari masing-masing dimensi dilakukan uji reliabilitas dengan nilai koefisien reliabilitas (alpha) > 0,6 dengan menggunakan bantuan program SPSS versi 20. Adapun hasil uji reliabilitas yang dilakukan terhadap instrumen penelitian ini dapat dijelaskan pada tabel berikut ini: 
Tabel 4.9

Hasil Uji Reliabilitas Butir Kuesioner

\begin{tabular}{|l|l|l|l|}
\hline No & $\begin{array}{l}\text { Butir } \\
\text { Dalam } \\
\text { Kuesioner }\end{array}$ & $\begin{array}{l}\text { Nilai } \\
\text { Alpha }\end{array}$ & Status \\
\hline 1 & $\mathrm{X}$ & 0,954 & Reliabel \\
\hline 2 & $\mathrm{Y}$ & 0,951 & Reliabel \\
\hline
\end{tabular}

Sumber : data primer (diolah), 2021

Dari hasil pengolahan data didapat koefisien reliabilitas (alpha) X(kualitas pelayanan) sebesar 0,954 dapat dikatakan reliabel atau terpercaya sebagai alat pengumpulan data dalam penelitian karena lebih besar dari 0,6.Untuk koefisien reliabilitas (alpha) Y (kepuasan konsumen) sebesar 0,951 dapat dikatakan reliabel atau terpercaya sebagai alat pengumpulan data dalam penelitian karena lebih besar dari 0,6. Jadi butir kuesioner kualitas pelayanan (X) dan kepuasan konsumen (Y) baik digunakan dalam penelitian ini.

\section{Analisis Data dan Uji Hipotesis}

\section{Analisis Regresi Sederhana}

Dari perhitungan analisis regresi sederhana dengan menggunakan SPSS versi 20 diperoleh hasil sebagai berikut :

$$
Y=15,810+0,374 X+e
$$

Dimana :

$\mathrm{Y}=$ Kepuasan Konsumen

$\mathrm{a}=$ Konstanta

$\mathrm{b}=$ Koefesien regresi

$\mathrm{X}=$ Kualitas Pelayanan $\mathrm{e}=$ error terms

Interprestasi dari persamaan regresi mengenaiPengaruh kualitas pelayanan terhadap kepuasan konsumen pada PT. JNE Cabang Sekayu dapat dijelaskan sebagai berikut :

a. Nilai konstanta sebesar15,810 menyatakan bahwa jika kualitas pelayanan $(\mathrm{X})$ nilainya adalah 0 , maka kepuasan konsumen (Y) nilainya adalah 15,810 .

b. Koefesien regresi untuk kualitas pelayanan (X) sebesar0,374 menyatakan bahwa setiap penambahan satu nilai kualitas pelayanan (X), maka nilai kepuasan konsumen (Y) bertambah sebesar 0,374 .

\section{Analisis Korelasi}

Setelah dilakukan analisis korelasi menggunakan program SPSS versi 20 diperoleh hasil sebagai berikut :

Diketahui nilai korelasi (R) sebesar 0,463, hal ini menunjukkan hubungan yang sedang karena berada di kisaran 0,40 - 0,599.

\section{Analisis Determinasi}

Berikut merupakan hasil analisis determinasi yang telah diolah menggunakan program SPSS versi 20 :

Diperoleh $\mathrm{R}^{2}$ ( $R$ square) sebesar 0,214, berarti pengaruh kualitas pelayanan terhadap kepuasan konsumen pada PT. JNE Cabang Sekayu sebesar $21,4 \%$ dan sisanya sebesar $78,6 \%$ dipengaruhi faktor lain yang tidak diteliti oleh peneliti.

Uji Hipotesis (Uji t) 
Diperoleh dari hasil pengelolahan komputerisasi menggunakan program SPSS versi 20 maka diperoleh nilai t hitung untuk $\mathrm{X}$ (kualitas pelayanan) sebesar 7,068 dengan t tabel sebesar 1,97287.

Dengan kriteria pengujian jika $t$ hitung>t tabel Ha diterima dan Ho ditolak, dan jika $t$ hitung < t tabel maka Ha ditolak dan Ho diterima. Dengan membandingkan $t$ hitung dan $t$ tabel untuk $X$ (kualitas pelayanan) diperoleh,t hitung $>t$ tabel yaitu 7,068>1,97287 maka Ha diterima dan Ho ditolak, berarti ada pengaruh signifikan antara $\mathrm{X}$ (kualitas pelayanan) dengan $\mathrm{Y}$ (kepuasan konsumen).

\section{Implementasi Hasil Penelitian}

Berdasarkan hasil pengolahan data dengan menggunakan SPSS versi 20, diperoleh nilai koefisien regresi pengaruh kualitas pelayanan terhadap kepuasan konsumen pada PT. JNE Cabang Sekayu adalah sebesar 0, 0,214, berarti pengaruh kualitas pelayanan terhadap kepuasan konsumen pada PT. JNE Cabang Sekayu sebesar 21,4\%. Nilai $t$ hitung sebesar $0,068>1,97287$ dengan nilai signifkansi sebesar 0,000 yang berarti Sig t $(0,000)<\alpha$ $(0,05)$. Hal tersebut berarti adanya pengaruh positif dari kualitas pelayanan terhadap kepuasan konsumen pada PT. JNE Cabang Sekayu.

Untuk mengatasi masalah kualitas pelayanan pimpinan harus memberikan arahan agar kualitas pelayanan yang diberikan kepada konsumen berjalan dengan baik, apabila arahan tidak berjalan dengan baik maka pemberian sanksi atau hukuman kepada karyawan yang tidak memberikan kualitas pelayan yang baik agar karyawan tersebut mematuhi setiap aturan dan bekerja dengan maksimal.

\section{SIMPULAN DAN SARAN}

\section{Simpulan}

Berdasarkan dari permasalahan yang dibahas maka dapat ditarik sebuah kesimpulan yaitu:

1. Berdasarkan perhitungan korelasi besarnya pengaruhkualitas pelayanan (X) terhadapkepuasan konsumen (Y) diperoleh korelasi (R) sebesar 0,463, hal ini menunjukkan hubungan yang sedang karena berada di kisaran 0,40 - 0,599.

2. Berdasarkan hasil perhitungan analisis determinasi diperoleh $\mathrm{R}^{2}$ ( $R$ square) sebesar 0,214, berarti pengaruh kualitas pelayanan terhadap kepuasan konsumen pada PT. JNE Cabang Sekayu sebesar $21,4 \%$ dan sisanya sebesar $78,6 \%$ dipengaruhi faktor lain yang tidak diteliti oleh peneliti.

3. Berdasarkan hasil pengujian hipotesis (uji t) diperoleh $\mathrm{t}$ hitung $>\mathrm{t}$ tabel yaitu 7,068>1,97287 maka Ha diterima dan Ho ditolak, berarti ada pengaruh signifikan antara $\mathrm{X}$ (kualitas pelayanan) dengan Y (kepuasan konsumen).

\section{Saran}

Ada beberapa saran yang perlu diperhatikan sehubungan dengan penelitian ini yaitu : 
1. Sebaiknya karyawan atau petugas PT JNE cabang Sekayu lebih mengutamakan kepentingan konsumen, memberikan perhatian kepada konsumen, merespon kebutuhankebutuhan yang konsumen inginkan bahkan terlebih daripada itu PT. JNE Cabang Sekayu lebih memperhatikan keamanan dan menjaga kepercayaan konsumen.

2. Agar dapat memberikan tingkat kepuasan yang tinggi kepada konsumennya, maka sebaiknya PT. JNE Cabang Sekayu perlu memberikan pelayanan yang baik dari segi kualitas fisik JNE seperti membuat gedung lebih menarik, bersih, serta menyediakan arena parkir yang lebih luas.

3. PT. JNE Cabang Sekayu harus memberikan pelayanan yang baik, dari segi kualitas kehandalan memberikan pelayanan secara maksimal serta pengiriman paket yang dilakukan secara tepat waktu dan sesuai.

4. Selain kualitas pelayanan, PT. JNE Cabang Sekayu harus mempertimbangkan faktor lain yang dapat meningkatkan kepuasan konsumen selain kualitas pelayanan.

\section{DAFTAR PUSTAKA}

Anonim. 2015. Pedoman Penyusunan Skripsi Sekolah Tinggi Ilmu Ekonomi Rahmaniyah. Sekayu: STIE Rahmaniyah Sekayu.

Arikunto, Suharsimi. 2013. Manajemen Penelitian. Jakarta: Rineka Cipta.
Garside, Annisa Kesy. 2017. Manajemen Logistik. Malang: UMM Press.

Ghozali, Imam. 2016. Aplikasi Analisis Multivariete Dengan Program IBM SPSS 23 (Edisi 8). Cetakan ke VIII. Semarang: Badan Penerbit Universitas Diponegoro.

Dutka, Alan. 2012. Atribut - Atribut Dari Konsumen Secara Universal. Jakarta: Glora Aksara Pertama.

Kasmir. 2017. Manajemen Sumber Daya Manusia. Jakarta: Raja Grafindo Persada.

Kotler, Philip dan Kevin Lane Keller. 2016. Marketing Management Edisi 14 Bahasa Indonesia. Jakarta: Indeks Gramedia.

Lupiyoadi, Rambat. 2014. Manajemen Pemasaran Jasa. Jakarta: Salemba Empat.

Ramli, Kamrianti. 2011. Skala Pengukuran dan Instrumen tian. Bandung: Deepublish.

Rohman, Abdur. 2017. Pengaruh Kualitas Pelayanan terhadap Kepuasan Konsumen Pelanggan Bengkel Mr. Montir TM Citayem. Jakarta: Universitas Islam Negeri Syarif Hidayatullah Jakarta.

Setyo, Triyono. 2020. Jurnal:Perkembangan E-commerce di Indonesia, diakses tanggal 18 Desember 2020.

Sujarweni, V. Wiratna. 2014. Metodologi Penelitian: Lengkap, Praktis, dan 
mudah dipahami. Yogyakarta: CV. Pustaka Baru Press.

Sugiyono. 2016. Metodologi Penelitian Bisnis. Edisi Kelima. Bandung: CV. Alfabeta.

Sunarti, Dwi Aliyyah Apriyani. 2017. Pengaruh Kualitas Pelayanan terhadap Kepuasan Konsumen (Survei pada Konsumen The Little a Coffe Shop Sidoarjo). Malang:Universitas Brawijaya Malang.

Tjiptono, Fandy. 2015. Pemasaran Strategik. Yogyakarta: Andi.

Wardani, Tri Ulpa. 2017. Pengaruh Kualitas Pelayanan terhadap Kepuasan Konsumen pada Bisnis Jasa Transportasi Gojek (Studi Kasus Mahasiswa FEBI UIN Sumatera Utara). Medan: UIN Sumatera Utara. 